\title{
Root uptake by cultivated vegetables of radionuclides coming from contaminated algae used as organic manure in soil
}

\author{
C. Colle, M. Masson ${ }^{1}$, P. Hurtevent, M. Morello and D. Hebert ${ }^{1}$
}

IPSN/DPRE/SERLAB/LRE, CE Cadarache, 13108 Saint-Paul-lez-Durance, France

${ }^{1}$ IPSN/DPRE/SERNAT/LERFA, BP. 10, 50130 Cherbourg-Octeville, France

\begin{abstract}
In certain areas of the French Atlantic coast, algae of marine origin are used as organic fertilizer, particularly for vegetables cultivation. An experiment was carried out to estimate the transfers of radioactivity towards agricultural productions which could result from this practice in the case where algae were contaminated. Algae (fucus vesiculosus) were cultivated in aquarium with sea water containing a mixture of radionucléides: ${ }^{22} \mathrm{Na}$, ${ }^{60} \mathrm{Co},{ }^{90} \mathrm{Sr},{ }^{99} \mathrm{Tc},{ }^{106} \mathrm{Ru},{ }^{125} \mathrm{Sb},{ }^{134,137} \mathrm{Cs},{ }^{238,239+240} \mathrm{Pu},{ }^{241} \mathrm{Am},{ }^{244} \mathrm{Cm}$. These algae were mixed, in a lysimeter, with a silty-sandy soil. Some vegetables, potatoes, lettuces, radishes, beans, tomatoes were cultivated on this manured soil. The soil to plant concentration ratios are given for the edible organs of the plants grown the year following the addition of algae in the soil and for cultures made several years later. On the other hand chemical extractions were performed to evaluate the bioavailable fraction of radionuclides in the soil.
\end{abstract}

\section{INTRODUCTION}

The use of algae from marine origin as an organic fertilizer is an ancient agricultural practice on an important part of the western French Atlantic seaboard. Although less usual nowadays, it is still used for the vegetables production, particularly in kitchen gardens near the coasts. Because of radionuclide discharges into the sea by nuclear installations and because some algae have a high potential to concentrate some chemical elements from sea water [2], an experiment was performed in order to estimate the impact of this agricultural practice on the radioactive contamination of the food chain. To this aim algae were artificially contaminated and used to fertilize a soil on which different kinds of vegetables were cultivated. The soil to plant transfers of the radionuclides were determined during the two growing seasons following the mixing of algae in the soil and then eight years later.

\section{MATERIALS AND METHODS}

\subsection{Contaminated algae production, soil contamination and radionuclides bioavailability in soil}

In 1990, algae (Fucus vesiculosus) were cultivated in an aquarium containing 80 liters of sea water spiked with a solution of various radioisotopes: ${ }^{22} \mathrm{Na},{ }^{60} \mathrm{Co},{ }^{90} \mathrm{Sr},{ }^{99} \mathrm{Tc},{ }^{106} \mathrm{Ru},{ }^{125} \mathrm{Sb},{ }^{134,137} \mathrm{Cs},{ }^{238,239+240} \mathrm{Pu},{ }^{241} \mathrm{Am}$, ${ }^{244} \mathrm{Cm}$. After contamination, these algae were mixed with a soil collected in a kitchen garden situated in the coastal area of the La Hague region and put in a lysimeter $\left(0.5 \mathrm{~m}^{2}\right.$ of cultivation area and $40 \mathrm{~cm}$ deep). The proportions were $2.5 \mathrm{~kg}$ of dry algae for $200 \mathrm{~kg}$ of dry soil. The main physico-chemical properties of this soil are indicated in Table 1.

Table 1 : Main physico-chemical characteristics of the cultivated soil

\begin{tabular}{|c|c|c|c|c|c|}
\hline $\mathrm{pH}\left(\mathrm{H}_{2} \mathrm{O}\right)$ & $\begin{array}{c}\mathrm{CEC} \\
\left(\mathrm{meq} \mathrm{kg}^{-1}\right)\end{array}$ & $\begin{array}{c}\text { Organic matter } \\
\left(\mathrm{g} \mathrm{kg}^{-1}\right)\end{array}$ & Clay (\%) & Silt (\%) & Sand (\%) \\
\hline 7.2 & 20 & 8 & 6.8 & 8.2 & 86.6 \\
\hline
\end{tabular}


The soil was maintained wet for one year and periodically mixed in order to allow the decomposition of algae and their homogeneous distribution in the lysimeter. At the end of this period of time, a composite sample was made from ten cores randomly sampled in the soil. This sample was mineralized and analysed for radionuclides. To estimate their bioavailability, extractions were applied in order to evaluate the hydrosoluble and the exchangeable forms (extracted by a solution of ammonium acetate $1 \mathrm{~N}$ )

\subsection{Soil to plant transfer experiments}

These studies were carried out from several growing seasons over a period of ten years according to the work schedule reported in Table 2. They concerned different kinds of crops : one leaf-vegetable (lettuces), two fruit-vegetables (beans and tomatoes) and two root-vegetables (potatoes and radishes).

Table 2 : Cultivation schedule

\begin{tabular}{|c|l|}
\hline Year & \\
\hline 1990 & Incorporation of contaminated algae in the soil \\
\hline 1991 & Lettuces cultivation \\
\hline 1992 & Potatoes and tomatoes cultivation \\
\hline 1993 & Tomatoes and beans cultivation \\
\hline 2000 & Lettuces and radishes cultivation \\
\hline
\end{tabular}

At harvest time the edible parts of all the vegetables were collected. After oven drying at $110^{\circ} \mathrm{C}$ until reaching a constant weight, the whole of each harvest was solubilized in wet way with nitric acid and hydrogen peroxyde. The solution obtained was used for the various treatments imposed by the specific procedure for the different radionuclides measurement, except for the technetium analysis which required a particular mineralization method.

\subsection{Radionuclides measurements}

Gamma emitter elements $\left({ }^{22} \mathrm{Na},{ }^{60} \mathrm{Co},{ }^{106} \mathrm{Ru},{ }^{125} \mathrm{Sb},{ }^{134,137} \mathrm{Cs}\right)$ were measured by high-resolution gamma spectrometry using an intrinsic Germanium coaxial detector.

Following a radiochemistry separation, transuranic elements $\left({ }^{238,239+240} \mathrm{Pu},{ }^{241} \mathrm{Am},{ }^{244} \mathrm{Cm}\right)$ were analysed by alpha spectrometry using silicium barrier detectors.

${ }^{90} \mathrm{Sr}$ measurements were carried out according to Tormos et al. [3].

${ }^{99} \mathrm{Tc}$ was analysed using the procedure described by Chen et al [4]. 


\section{RESULTS AND DISCUSSION}

\subsection{Soil radionuclides content and bioavailability}

The soil content of radionuclides originating from contaminated Fucus vesiculosus is reported in Table 3. Some others nuclides which were detected in the algae such as ${ }^{22} \mathrm{Na}$, were below the detection limits in the soil.

Table 3 : Soil radionuclides content ( $\mathrm{Bq} \mathrm{kg}{ }^{-1}$ dry soil)

\begin{tabular}{|c|c|c|c|c|c|}
\hline${ }^{60} \mathrm{Co}$ & $90 \mathrm{Sr}$ & $99 \mathrm{Tc}$ & $106 \mathrm{Ru}+106 \mathrm{Rh}$ & $125 \mathrm{Sb}$ & ${ }^{134} \mathrm{Cs}$ \\
\hline $5 \pm 1$ & $212 \pm 23$ & $2602 \pm 193$ & $6062 \pm 380$ & $673 \pm 29$ & $23 \pm 3$ \\
\hline
\end{tabular}

\begin{tabular}{|c|c|c|c|c|c|}
\hline $137 \mathrm{Cs}$ & $238 \mathrm{Pu}$ & $239+240 \mathrm{Pu}$ & $241 \mathrm{Am}$ & ${ }^{242} \mathrm{Cm}$ & ${ }^{244} \mathrm{Cm}$ \\
\hline $76 \pm 4$ & $0.19 \pm 0.02$ & $0.13 \pm 0.02$ & $1.49 \pm 0.14$ & $0.041 \pm 0.008$ & $1.67 \pm 0.15$ \\
\hline
\end{tabular}

The chemical extractions performed to estimate the bioavailability of the radionuclides indicate that, one year after the incorporation of the contaminated algae in the soil, the total amount of the hydrosoluble faction and of the exchangeable fraction was $47.4 \%, 42 \%, 19.8 \%, 21.5 \%$ and $10.8 \%$ of the total contents of the soil respectively for strontium, ruthenium, antimony, cesium and americium. The other elements were not detectable. Concerning technetium the measurements have not been made so far, for lechnical reasons. These relatively important percentages are probably due to the weak capacity of the soil to retain these nuclides because of its sandy texture, its weak cationic exchange capacity and of its low organic matter content.

\subsection{Soil to plant transfers}

The soil/plant concentration ratio is defined as the content of the nuclide per unit weight of the plant organ at harvest $\left(\mathrm{Bq} \mathrm{kg}^{-1}\right)$ divided by the concentration of the nuclide per unit weight of dry soil $\left(\mathrm{Bq} \mathrm{kg}^{-1}\right)$. The calculations of the concentration ratios, listed in Table 4, are made on a wet and on a dry weight basis for the plants.

In consistance with the results of the bioavailability determination, these results show that a significant amount of radionuclides which were incorporated by algae, became available for root uptake by cultivated vegetables.

These experimental soil/plant concentration ratios are within the range of those reported by the International Atomic Energy Agency [1] for the same kinds of crops (table 5) and for a sandy soil in the case of cesium, strontium, plutonium, americium. They are higher for ruthenium and antimony, lower for strontium and technetium. 
Table 4 : Soil/plant concentration ratio (CR) for the edible parts of the investigated vegetables

\begin{tabular}{|c|c|c|c|c|c|}
\hline Radionuclides & Vegetables & Year & Plant organs & $\begin{array}{c}\mathrm{CR} \\
\left(\mathrm{Bq} \mathrm{kg}{ }^{-1} \text { fresh/Bq kg-1 dry) }\right. \\
\end{array}$ & 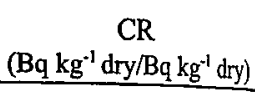 \\
\hline \multirow[t]{2}{*}{${ }^{60} \mathrm{Co}$} & Lettuce & 1991 & Leaves & 0.052 & 0.83 \\
\hline & \multicolumn{5}{|c|}{ Not detected in the harvests $1992,1993,2000$} \\
\hline \multirow[t]{6}{*}{${ }^{90} \mathrm{Sr}$} & Lettuce & 1991 & Leaves & $5.810^{-2}$ & 0.82 \\
\hline & Potato & 1992 & Tubers & $4.810^{-2}$ & 0.34 \\
\hline & Tomato & 1992 & Fruits & $1.710^{-2}$ & 0.12 \\
\hline & Tomato & 1993 & Fruits & $2.810^{-2}$ & 0.26 \\
\hline & Bean & 1993 & Pods & $1.510^{-2}$ & 0.18 \\
\hline & \multicolumn{5}{|c|}{ Not detected in the harvests 2000} \\
\hline
\end{tabular}

${ }^{99} \mathrm{Tc}$

\begin{tabular}{|c|c|c|c|c|c|}
\hline & & & & & \\
\hline & Lettuce & 2000 & Leaves & 2.6 & 33 \\
\hline & Radish & 2000 & Roots & 0.2 & 3 \\
\hline \multirow[t]{5}{*}{${ }^{106} \mathrm{Ru}$} & Lettuce & 1991 & Leaves & $1.210^{-2}$ & 0.21 \\
\hline & Potato & 1992 & Tubers & $5.310^{-2}$ & 0.37 \\
\hline & Tomato & 1992 & Fruits & $2.110^{-2}$ & 0.14 \\
\hline & Tomato & 1993 & Fruits & $5.110^{-2}$ & 0.47 \\
\hline & Bean & 1993 & Pods & $3.310^{-2}$ & 0.39 \\
\hline
\end{tabular}

$125 \mathrm{Sb}$

$\begin{array}{lll}\text { Lettuce } & 1991 & \text { Leaves } \\ \text { Potato } & 1992 & \text { Tubers } \\ \text { Tomato } & 1992 & \text { Fruits } \\ \text { Tomato } & 1993 & \text { Fruits } \\ \text { Bean } & 1993 & \text { Pods }\end{array}$

$0.510^{-2}$

0.08

$2.110^{-2}$

0.15

Tomato

$1.710^{-2}$

0.12

Tomato

1993 Pods

$2.110^{-2}$

0.19

Not detected in the harvests 2000

\begin{tabular}{|c|c|c|c|c|c|}
\hline \multirow[t]{6}{*}{${ }^{137} \mathrm{Cs}$} & Lettuce & 1991 & Leaves & $3.710^{-2}$ & 0.62 \\
\hline & Potato & 1992 & Tubers & $1110^{-2}$ & 0.79 \\
\hline & Tomato & 1992 & Fruits & $910^{-2}$ & 0.60 \\
\hline & Tomato & 1993 & Fruits & $710^{-2}$ & 0.58 \\
\hline & Bean & 1993 & Pods & $1.310^{-2}$ & 0.15 \\
\hline & \multicolumn{5}{|c|}{ Not detected in the harvests 2000} \\
\hline \multirow[t]{2}{*}{$238 \mathrm{Pu}$} & Potato & 1992 & Tubers & $1.310^{-4}$ & $910^{-4}$ \\
\hline & \multicolumn{5}{|c|}{ Not detected in the harvests $1991,1993,2000$} \\
\hline \multirow[t]{2}{*}{$239+240 \mathrm{Pu}$} & Potato & 1992 & Tubers & $1.710^{-4}$ & $1210^{-4}$ \\
\hline & \multicolumn{5}{|c|}{ Not detected in the harvests $1991,1993,2000$} \\
\hline \multirow[t]{5}{*}{${ }^{241} \mathrm{Am}$} & Lettuce & 1991 & Leaves & $0.1110^{-2}$ & $1.810^{-2}$ \\
\hline & Potato & 1992 & Tubers & $1.210^{-3}$ & $8.210^{-3}$ \\
\hline & Bean & 1993 & Pods & $0.710^{-4}$ & $810^{-4}$ \\
\hline & Lettuce & 2000 & Leaves & $0.210^{-3}$ & $910^{-3}$ \\
\hline & Radish & 2000 & Roots & $0.710^{-4}$ & $910^{-4}$ \\
\hline
\end{tabular}


Table 5 : Soil to plant transfer factors values (Bq. $\mathrm{kg}^{-1}$ dry vegetable by $\mathrm{Bq} . \mathrm{kg}^{-1}$ dry soil) reported by the IAEA [1] .

\begin{tabular}{|l|c|c|c|c|c|c|c|}
\hline & Sr & Tc & Ru & Sb & Cs & Pu & Am \\
\hline Green vegetables & 3.0 & 200 & 0.2 & $*$ & 0.46 & $7.310^{-5}$ & $6.610^{-4}$ \\
\hline Root crops & 1.4 & 79 & 0.04 & $5.610^{-4}$ & 0.01 & $7.710^{-4}$ & $1.410^{-3}$ \\
\hline Tubers & 0.26 & 0.24 & $*$ & $*$ & 0.17 & $1.510^{-4}$ & $2.010^{-4}$ \\
\hline Bean & 2.2 & 4.3 & 0.04 & $*$ & 0.094 & $6.110^{-5}$ & $3.910^{-4}$ \\
\hline
\end{tabular}

\section{CONCLUSION}

The use of seaweeds to fertilise cultivated soils appears to be an agricultural practice able to contribute to the contamination of the human food chain. In the hypothesis of a chronic radioactive pollution of the sea water, algae like Fucus vesiculosus, could constitute a chronic source of contamination for the agricultural soils on which they would be spread every year. This practice would lead to an enrichment of soils with radionuclides. This phenomenon should be considered more especialy in the case of long lived nuclides such as technetium-99 and transuranics elements.

\section{Acknowledgments}

The authors are grateful to D. Poncet-Bonnard for radioactive measurements.

\section{REFERENCES}

[1] I.A.E.A., Handbook of parameters values for the prediction of radionuclides transfer in temperate environments. Technical report series $N^{\circ} 364$, (IAEA, Vienne, 1994).

[2] Ancellin J., Guegueniat P., Germain P. Radioécologie Marine. Etude du devenir des radionucléides rejetées en milieu marin et applications à la radioprotection. Paris : Eyrolles, (1979) $256 \mathrm{p}$.

[3] Tormos J., Jouve A., Revy D., Millan-Gomez R., Zanon R., Erario M.J. A rapid method for determining strontium-90 in contaminated samples of soil and plant. J. Environ. Radioactivity 27 (3) (1995) 193-206.

[4] Chen Q., Dahlgaard H., Hansen H.J.M., and Aarkrog A. determination of ${ }^{99}$ Tc in environmental samples by anion exchange and liquid-liquid extraction at controlled valency. Anal.Chim.Acta, 228 (1990) 163-167. 